Western North American Naturalist 68(2), (C) 2008, pp. 241-244

\title{
FEEDING BY THE GREAT BASIN SPADEFOOT TOAD (SPEA INTERMONTANA [COPE]) (ANURA: PELOBATIDAE)
}

\author{
Richard S. Zack ${ }^{1,2}$ and Diana G. Johnson ${ }^{1}$
}

\begin{abstract}
The present study analyzed the stomach contents of 65 Great Basin spadefoot toads, Spea intermontana (Cope), collected in an area of irrigation runoff in south central Washington State. Toads were collected by pitfall trapping. Traps were maintained for 1 year beginning in April 2002. Toads consumed at least 56 different arthropod taxa belonging to the orders Coleoptera, Diptera, Hemiptera, Hymenoptera, Lepidoptera, Neuroptera, Orthoptera, Trichoptera, Collembola, and Araneae. Ants and darkling beetles were among the most common prey. Feeding appeared to be very generalized with the toads accepting almost anything they could capture and subdue.
\end{abstract}

Key words: Spea intermontana, gut contents, stomach contents, arthropods as food, Great Basin spadefoot.

The Great Basin spadefoot toad, Spea intermontana (Cope), occurs throughout the arid areas of the Great Basin including portions of Nevada, Utah, northern Arizona, and southwestern Wyoming, as well as much of eastern Washington, eastern Oregon, southern Idaho, and south central British Columbia (Tanner 1939, Stebbins 1951, Nussbaum et al. 1983, Cannings 1999). Spadefoot toads are well adapted to xeric environments. During the day, or during extended cold or dry periods, the toads will burrow or enter underground rodent burrows where they can remain inactive for periods as long as 8 months (Green and Campbell 1984, Cannings 1999). Breeding takes place early in the summer and larval development can be completed in as little as 6 weeks (Green and Campbell 1984). This rapid, early larval development is critical for toads that breed in ephemeral pools. Morey (2005) presents an excellent discussion of the biology and conservation status of the toad.

Little dietary information is available for Spea intermontana. It is thought that these toads forage on rainy or moist nights (Nussbaum et al. 1983, Cannings 1999). Tanner (1931) reported that 5 toads collected in Utah had a variety of insects in their stomachs including ants, darkling beetles (Tenebrionidae: Eleodes), ground beetles (Carabidae), a larval predaceous diving beetle (Dytiscidae), a grasshopper, an ichneumonid wasp, and a cricket (Gryllidae). Other discussions are generic in nature and state that the toads feed on a variety of invertebrates (Nussbaum et al. 1983, Cannings 1999).

\section{Methods}

The study was conducted in Grant County in south central Washington State. Climate in the study area comprises hot, dry summers and cold winters, with annual precipitation ranging from 10 to $20 \mathrm{~cm}$. Temperature ranges from average highs of $3^{\circ} \mathrm{C}$ in January to $33^{\circ} \mathrm{C}$ in July; temperatures of $32^{\circ} \mathrm{C}$ or above occur an average of 56 days per year (ERDA 1975). The generalized habitat is stabilized sand with sparse sagebrush (Artemisia tridentata Nutt.), rabbitbrush (Chrysothamnus viscidiflorus [Hook.] Nutt.), buckwheat (Eriogonum niveum Dougl. ex Benth.), and cheatgrass (Bromus tectorum L.) as the dominant plant taxa.

An irrigation runoff system empties throughout the area and forms various lakes, shallow ponds, and canal systems. Water levels in these catch basins fluctuate throughout the year with periods of total dryness. The study site was established at the low end of the catch-basin where water reached its maximum in late July through mid-August. These pools reach a maximum depth of only $20-30 \mathrm{~cm}$. Toads were collected in traps located 25-200 meters from the closest source of water when the water level was the highest. In general, toads were collected in larger numbers in pitfall traps that were closest to the water.

${ }^{1}$ Department of Entomology, Washington State University, Pullman, WA 99164-6382.

22E-mail: zack@wsu.edu 


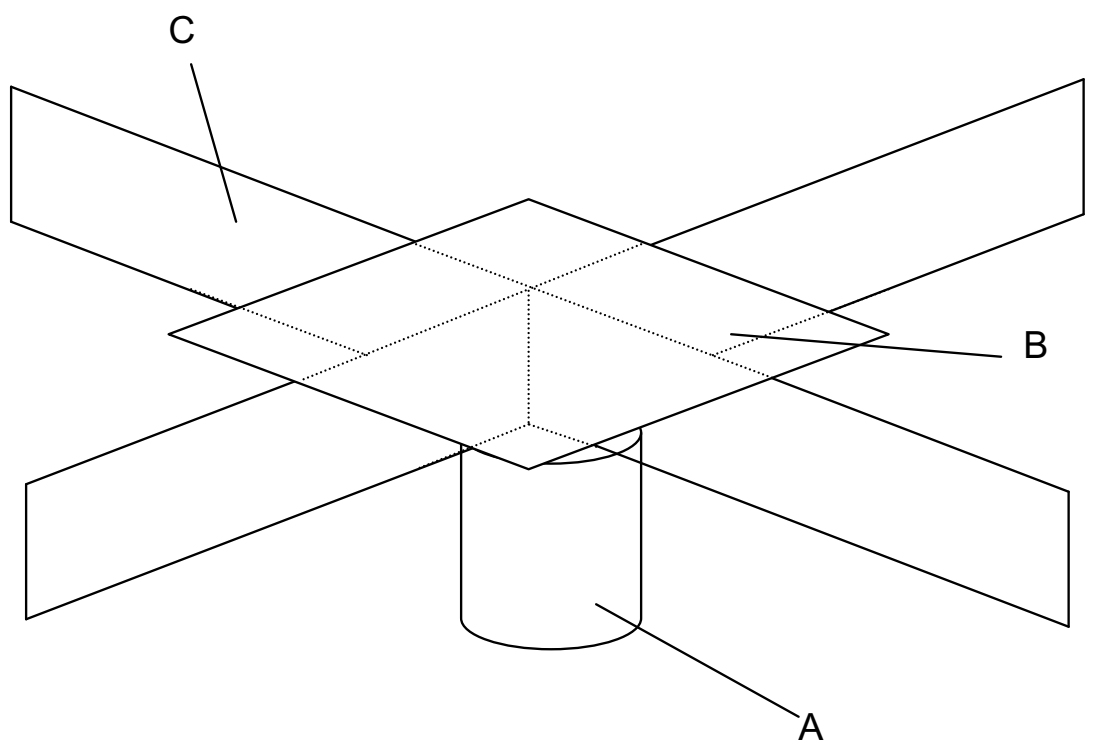

Fig. 1. Schematic of pitfall trap: A, trap receptacle; B, cover; C, baffles.

We established a linear transect of 10 pitfall traps, spaced $10 \mathrm{~m}$ apart. Pitfall traps consisted of "1-pound" plastic deli cups with an open top diameter of approximately $11.5 \mathrm{~cm}$ and a depth of approximately $8.25 \mathrm{~cm}$. We buried the cups flush with the soil and covered each with an X-shaped set of 7.5-cm-high baffles with a span of $46 \mathrm{~cm}$ from the center of the trap. A 30.5-cm square lid was placed over the baffles and was centered on the center of the trap (Fig. 1). Cups were filled to a depth of approximately $2.5 \mathrm{~cm}$ with propylene glycol (Sierra ${ }^{\circledR}$ brand) diluted 1:1 with water. We initiated traps on 11 April 2002 and collected approximately weekly until 11 April 2003.

Collected toads were transferred from the propylene glycol to $70 \%$ ethanol within a day after collection. Snout-vent measurements of each toad were made prior to removing the digestive system and identifying the contents. Toads and their gut contents were preserved in $70 \%$ ethanol.

\section{Results AND Discussion}

We examined stomach contents from 65 toads. The 1st toads were captured during the 1st week of trapping, 11-20 April. Toads were taken regularly until 21-28 June, when no toads were captured. We again collected toads until the period 9-30 August, during which 3 weekly collections were made. This was a dry and hot period, and toads may have remained in their burrows during most of the month of August. During the 3 collection periods between 30 August and 20 September, toads were taken each week. No toads were collected between 20 September and 4 October, and only 1 toad was taken during the period 4-11 October. No toads were captured from 11 October to 14 March. Two toads were collected between 14 March and 21 March, but none were collected from 14 March to the time when the traps were removed on 11 April. The maximum number of toads collected during any period was 9 for 5-12 July; the average number taken during weeks in which toads were captured was 3.1. It must be noted, however, that because of strong winds, traps were often dislodged or filled with sand and proved to be nonfunctional during certain weeks.

Toads began to appear at least 3 months before the water reached its maximum depth and nearest distance to the traps. During April, when the 1st toads were taken, water was approximately $1 \mathrm{~km}$ from the traps. Although several searches were made for toads during daylight and nighttime hours, no toads were ever encountered. A pool that formed within approximately $200 \mathrm{~m}$ of the pitfall traps was examined on 19 July and tadpoles were found. Although we assume these were tadpoles of 
TABLE 1. Taxonomic listing of arthropods found in the stomachs of the Great Basin spadefoot toad.

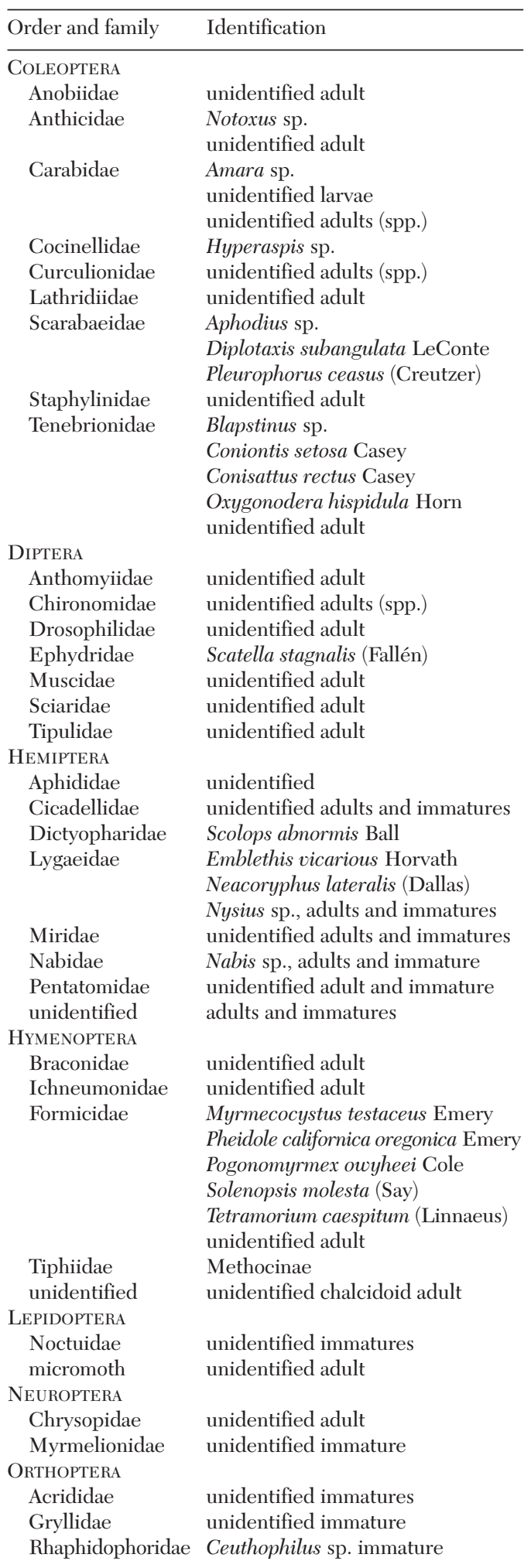

TABLE 1. Continued.

\begin{tabular}{cl}
\hline TRICHOPTERA & \\
Hydroptilidae & unidentified adult \\
unidentified & unidentified adult \\
COLLEMBOLA & \\
unidentified & \\
ARANEAE & \\
unidentified & $\begin{array}{l}\text { mostly small specimens (probably } \\
\text { immatures) of various species }\end{array}$ \\
\hline
\end{tabular}

the Great Basin spadefoot toad, we did not verify it.

Table 1 is a comprehensive list of arthropod taxa taken from the digestive systems of the toads. Some toads had large numbers of a single taxon of insect (e.g., chironomid midge adults or the ant Tetramorium caespitum [L.]), while others contained 10-12 different taxa. Only 3 of the 65 toads had empty stomachs. The toads occasionally had small amounts of vegetation and a few small pebbles or sand grains in their stomachs, which may have been taken accidentally. No toad appeared to feed on vegetation as a primary nutritional source. One toad, collected between 11 April and 20 April, had large amounts of vegetation in its gut but also 2 large, intact caterpillars and 2 partially digested caterpillars, which were probably the source of the plant material.

From the data presented in Table 1, it appears that the toads are generalists that consume a large variety of easily captured and subdued arthropod prey. In general, these arthropods reflect those that were taken in the pitfall traps at the time when the toads also were collected. Within their feeding constraints, the toads do not appear to select any specific prey items over others. Almost all toads had eaten $>1$ prey taxon. Certain ants (Formicidae) and darkling beetles (Tenebrionidae) were most consistently taken by the toads, but these also are the most frequent species of arthropods in the traps. However, there are some noteworthy differences between toad gut contents and trap catches.

Although at least 5 species of darkling beetles were captured by the toads, only one, Conisattus rectus Casey, was very common. Conisattus rectus is a medium-sized beetle reaching 6-7 $\mathrm{mm}$ in length. Several other species of darkling beetles were also very common in the traps but were never found in the toads. These species, which include several Eleodes spp. and range from $9 \mathrm{~mm}$ to $35 \mathrm{~mm}$, 
are probably too large for the toads to capture. Additionally, at least 10 species of ground beetles (Carabidae) were taken in the pitfall traps but only 1 genus, Amara spp., and 1 other unidentified species were found in the toads. Most of these ground beetles are within the feeding size range of the toads if one uses the darkling beetles as a guide, but the ground beetles may be too active or distasteful, or produce a noxious secretion. While little is known concerning the defensive mechanisms of ground beetles encountered in this study, others (Eisner et al. 2005) are known to produce defensive secretions.

Ants, especially Tetramorium caespitum (Linnaeus), are very common in toad stomachs and in the traps. Not only is this ant commonly taken in traps, but specimens were found in most of the 10 traps throughout study. Other ants, such as Solenopsis molesta (Say) and Pheidole californica oregonica Emery, were more localized in specific traps, probably reflecting a colony near those traps. The lesser presence and abundance of these latter ants in the toads reflects their patchy distribution. A commonly occurring ant, Pogonomyrmex owyheei Cole, was found in toads only during the period 19-26 July and in very low numbers. This stinging harvester ant may be avoided by the toads or may not be active when the toads are feeding.

From a conservation standpoint, the fact that the toads are very generalized in their feeding is encouraging. If water is available for larval development and the soil permits burrowing, toads appear to have a good chance of establishing and maintaining populations. Nussbaum et al. (1983) speculated that irrigation might be helping to create new habitat for colonization within the distribution range of the Great Basin spadefoot toad. Hovingh et al. (1985) found that in the Bonneville Basin, Utah, over half of the breeding sites for the toad are man-made reservoirs, and Morey (2005) states that the toads have taken advantage of artificial water sources to increase their abundance. The present study appears to corroborate their hypothesis. Previous to irrigation, this area of shrubsteppe had no standing water. With the development of the irrigation runoff system, hundreds of acres were made available to the toads; and, although our data do not quantify toad abundance, they do indicate that toads are present and that there are abundant prey to sustain them.

\section{ACKNOWLEDGMENTS}

We wish to thank Dennis Strenge and Christophor Looney for helping in the collection of trap contents. Drs. David Smith (USDAARS Systematic Entomology Lab., Washington, DC) and Charles A. Triplehorn (Ohio State University) aided in the taxonomic determinations of ants and darkling beetles, respectively. This project was part of a larger biological diversity study funded by The Nature Conservancy (TNC). The support of TNC for entomological diversity studies at various locations throughout Washington State is acknowledged and greatly appreciated. Anonymous reviewers and editors of Western North American Naturalist provided constructive criticism of the manuscript.

\section{Literature Cited}

Cannings, R.J. 1999. Great Basin spadefoot toad [online brochure]. British Columbia Ministry of Environment, Lands and Parks. Accessed 11 June 2007. Available from: http://wlapwww.gov.bc.ca/wld/document/spadefoottoad.pdf

Eisner, T., M. Eisner, and M. Seigler. 2005. Secret weapons: defenses of insects, spiders, scorpions, and other many-legged creatures. Harvard University Press, Cambridge, MA.

[ERDA] Energy Research and Development AdminisTRATION. 1975. Final environmental statement, waste management operations. ERDA-1538, Volume 1. Energy Research and Development Administration, Richland, WA.

Green, D.M., and R.W. Campbell. 1984. The amphibians of British Columbia. Handbook 45, Royal British Columbia Museum.

Hovingh, P., B. Benton, And D. Bornholdt. 1985. Aquatic parameters and life history observations of the Great Basin spadefoot toad in Utah. Great Basin Naturalist 45:22-30.

Morey, S.R. 2005. Spea intermontana (Cope, 1883) Great Basin spadefoot. Pages 517-519 in M. Lannoo, editor, Amphibian declines: the conservation status of United States species. University of California Press, Berkeley. 1094 pp.

Nussbaum, R.A., E.D. Brodie, JR., and R.M. Storm. 1983. Amphibians and reptiles of the Pacific Northwest. Northwest Naturalist Book, University of Idaho Press, Moscow.

StebBins, R.C. 1951. Amphibians of western North America. University of California Press, Berkeley. 539 pp.

Tanner, V.M. 1931. A synoptic study of Utah Amphibia. Transactions of the Utah Academy of Sciences 8: 159-198.

1939. A study of the genus Scaphiopus. Great Basin Naturalist 1:3-20.

Received 19 September 2007 Accepted 8 January 2008 